\title{
The Relationship between the Attitudes of Mathematics Teacher Candidates towards Scientific Research and Their Thinking Styles ${ }^{\mathrm{i}}$
}

\author{
Hasibe İnce ${ }^{1}$, Selin Çenberci ${ }^{2}$, Ayşe Yavuz ${ }^{2}$ \\ ${ }^{1}$ Institute of Educational Sciences, Necmettin Erbakan University, Meram, Konya 42090, Turkey \\ ${ }^{2}$ Department of Math Education, Ahmet Keleşoğlu Faculty of Education, Necmettin Erbakan University, Meram, Konya 42090, Turkey
}

Copyright $\bigcirc 2018$ by authors, all rights reserved. Authors agree that this article remains permanently open access under the terms of the Creative Commons Attribution License 4.0 International License

\begin{abstract}
The aim of this research is to determine the attitudes of mathematics teacher candidates towards scientific research and their thinking style and whether there is a significant relationship between these two. The sample of the research is constituted of 83 second year students studying at the Mathematics Education Department, Ahmet Keleşoğlu Education Faculty, Necmettin Erbakan University in the spring semester of 2017-2018 academic years. The relational screening model was used in the analysis of the data. The 'Thinking Styles Scale' developed by Sternberg and Wagner [47] and adapted to Turkish by Bulus [8], and the 'Attitude Scale towards Scientific Research' developed by Korkmaz, Şahin and Yeşil [31] were used as data collection tools in the research. Research findings show that there is no significant relationship between the thinking styles of the teacher candidates and their attitudes towards scientific research. It was found that the highest relationship was between positive attitudes toward research and open-minded (liberal) thinking styles.
\end{abstract}

Keywords Teacher Candidates, Thinking Styles, Attitude towards Scientific Research

\section{Introduction}

The most obvious ability that distinguishes man from other living things is power of thinking. We are constantly realizing the thinking action in our daily life. While eating, at school, at work and resting, our brain is busy with many thoughts. Thinking is denominated as active mental process made for understanding the situation in which we are involved [15]. Thinking, in the most general sense, can be defined as finding of the probabilities, possible actions, beliefs and individual goals, and making selection from among the possibilities [4]. Thinking is defined by Özden
[38] as conceptualization, implementation, analysis and arrangement of the information obtained through channels such as observation, experience, intuition and reasoning. This is a process and it is defined as turning objects and events in the outer world into symbols, according Arkonaç [2]. In [21] stated that this process is composed of a number of components, such as problem solving, decision making, critical thinking, logical reasoning, and creative thinking.

Thinking is ability, and can be directly taught and improved. In this context, the aim of education is not only to acquire knowledge but also it should cover organizing and developing high-level thinking

strategies for creative thinking, critical thinking and problem solving [16]. The development of the societies is possible by educating individuals, who can think, who are imaginative, and have reasoning power.

Individuals prefer different methods when performing thinking activities. Just as individuals differ in terms of interest, pleasure, living and experiences, the ability to think also varies from person to person. Namely, each individual has different ways of thinking. In this context, it can be stated that the thinking styles of people have been composed because their reaction to the problems that they have encountered from past to present and their ways of producing solution to these problems are different in [13]. In addition, the thinking style can be used to describe the way that a person prefers when learning of the knowledge or learning how to think about this knowledge [53]. Stenberg [46] described thinking style not only as ability but rather as a preference way of individual in the use of the ability and as a preferred way of thinking. According to Sternberg, people have a style profile rather than a single style. Because the styles can be changed according to the conditions and the conditions can be diversed throughout life. In addition, the styles can be taught that they can be measured under appropriate environmental and laboratory conditions. For this reason, people differ from each other in terms of flexibility and power of style [7]. There is no good 
or bad style, and the effects of the styles differ according to the time-varying.

When the literature is examined, it is seen that various theories and different points of view about the thinking styles were put forth. The most common theory regarding people's thinking style is the "Theory of Mental Autonomy" which was asserted by Sternberg [41], [42], [43], [44], [45]. This theory refers to 13 styles of thinking in 5 different dimensions. These dimensions are functions, forms, levels, scopes, and leanings [7], [8].

1. Functions: There are three thinking styles take part in this dimension such that legislative, executive and judicial. Individuals who have a style of legislative thinking like finding solutions for problem and set their own rules, and prefer unstructured problems. The focus is creativity and design. Individuals, who have the style of legislative thinking, produce original ideas and are innovators. Individuals who have executive thinking style are individuals who like doing things in known ways by preferring problems which are pre-configured, and have rules. They act according to the regulation, they are application-focused. Individuals who have judicial thinking style enjoy judging events and cases, and evaluate existing situations and considerations.

2. Forms: There are four styles of thinking at this dimension: monarchic, hierarchic, oligarchic, and anarchic. Individuals who have a monarchical thinking style work on a single goal mentally; perfectionism is the most prominent feature of it. Individuals having a hierarchical thinking style act by considering a number of objectives with different priorities and know that some goals are more important than others, and they set priority orders and work systematically. Individuals having an oligarchic thinking style focus on many subjects at the same time, and dislike determining the priority order. The rules and the processes of applying them have no meaning for individuals who have an anarchic thinking style. They prefer to deal with stress-free works which are quite comfortably. They avoid being attached to something.

3. Levels: This dimension includes local and global thinking styles. People with a global thinking style are interested in abstract issues, and they are interested in whole of picture without considering details. Individuals who have a local way of thinking are pleased with concrete and detailed workings.

4. Scopes: There are two different types of thinking styles in this dimension, the internal and the external thinking styles. Those who have an internal thinking style are introverted, subject-centered, cold-indifferent, and little social.
They like individuality. Basically, their preferences are to act in line with their own principles and thoughts as independently of others. Persons with an external thinking style are human-centered and social at a high level. They like to work with other people; group work is very suitable for these individuals.

5. Leanings: There are two types of thinking styles in this dimension: The conservative thinking style and the open-minded (liberal) thinking style. Individuals with conservative thinking style stay as far away as possible from uncertainty. They use well-attested methods. Individuals with a liberal-thinking style are open to innovation and change, and prefer to deal with uncertain and questionable situations.

The science is defined as regular information and discipline, which selects a part of the events or universe as field of subject and tries to draw conclusions by using the facts and methods based on the experiment [49]. In addition to these, 'the whole of approved systematic information' and 'the form of recorded systematic information collected by human beings', are used for science. Karasar describes the research as the process of collecting, analyzing, interpreting, evaluating and reporting the data in a planned and systematic manner in order to find reliable solutions to the problems [28].

Scientific research, on the other hand, is to produce information by using a goal, stage and method for obtaining new information, and make an effort to gather the produced information. One of the most characteristic features of scientific research is that it consists of some successive steps. The research process that begins with the feeling of the problem includes the process of determination of the methods to be followed and the steps to be taken to fulfill the needs, collecting the data, processing the data, developing conclusions and suggestions by looking at data, and recording conclusions and process ([33], [12], [6], [32]).

The development level of societies in the age of science and technology are measured by the importance that they place on scientific research. For this reason, individuals are expected to be ones who have scientific thinking skills, and are producing, thinking creatively and questioning. Making individuals have scientific thinking skills is the most basic task of the educational institutions ([14], [24], [26], [27], [36]).

The influence of teachers cannot be ignored in these educational institutions. Teachers have crucial tasks, especially at the point of bringing research cultures and scientific perspectives to students and developing positive attitudes towards researches and researchers. In this context, "Scientific Research Methods" is taught in many departments in universities, in all departments of Education Faculties and in many programs of vocational colleges. Through these lessons, the research knowledge of the 
students is developed and it is aimed that the students obtain positive attitudes towards research [31].

It was encountered what are the thinking styles of teacher and teacher candidates in the literature, and that examination of these styles in terms of various variables. Çubukçu [15] observed that teacher candidates preferred the legislative and hierarchical thinking styles as a result of the study which aimed at determining the thinking styles of them and done by participating of 90 students. It was also observed in the same study that the thinking styles differed according to the branches of the teacher candidates and the activities chosen.

Buluş [8], also examined the relationship of thinking styles with academic success in his study in which reliability and validity of the thinking style scale were tested. As a result of the research, it was found negative relationship between the anarchic and conservative thinking style and the academic achievement. Başol and Türkoğlu [5], in their study, examined the relationship between the thinking styles of classroom teacher candidates and control-oriented situations. It is concluded that there is a relationship between the thinking styles and the being of control-oriented situations as internal or external. There was a significant negative relationship between control status of teacher candidates and subjective and hierarchic thinking styles.

It has been encountered a number of studies in which thinking styles have been examined in terms of demographic features such as the gender, age, graduated high school, program where education received, grade level, vocational seniority, and culture in which person gets involved ([39], [1] [18], [35], [22]). Dinçer and Saracaloğlu [19] examined the thinking style profiles of teacher candidates in terms of various variables in the study carried out with the participation of 339 teacher candidates who are studying in Classroom teaching, Mathematics, Social Studies and English programs of Dokuz Eylül University, Buca Education Faculty. It was concluded that there was a statistically significant difference between the thinking style of teacher candidates and class, gender, age, graduated department, socioeconomic level perception. It was found that there was a low-level and negative directional relationship between academic grade-point averages of teacher candidates and their global and conservative thinking styles.

Duman and Çelik [20] conducted their study named 'The Relationship between the Thinking Styles of Elementary School Teachers and Their Teaching Methods' with the participation of 101 teachers. Teachers preferred hierarchical, legislative and executive thinking styles at most and they preferred at least oligarchic, conservative and elaborate thinking styles. While the thinking styles of teachers did not show any significant difference in accordance with branch and gender variables, it was found a significant positive directional relationship between the other styles except for legislative, oligarchic and conservative thinking styles and the scores that teachers got from the teaching methods questionnaire.

Canbolat [11] observed that thinking styles and technological pedagogical domain knowledge of primary school mathematics teacher candidates differ in accordance with gender, class, and whether they have computer or not in master thesis. Moreover, it was concluded in the same study that judgmental, innovative, staged thinking styles were significantly related to technological pedagogical domain knowledge subdimensions rather than other thinking styles.

Emir [23] aimed to determine the power of thinking styles in predicting critical thinking tendencies of in his research, performed in 2013. The positive relationship to large extend was determined between the thinking styles and the critical thinking tendencies in the research, conducted with the participation of 430 teachers working in primary education. As result of the research, it was observed that each of the thinking styles predicted one or more of the critical thinking tendencies.

The relationship of thinking styles with measurement and evaluation methods was investigated in the study, conducted by Özbaş and Uluçınar [37]. As a result of the research, they reached to conclusion that classroom teachers have legislative, executive and hierarchical thinking styles at most and local, global and conservative thinking styles at least. Additionally, while it was found that liberal and conservative thinking styles have no significant relationship with any measurement-evaluation method, it was found that there was a significant relationship between the use of other thinking styles and various measurement-evaluation methods.

It is seen that there are various researches for determining the attitudes of teachers and teacher candidates towards researchers and scientific researches, as well as all other studies. Korkmaz, Şahin and Yeşil [30] stated that attitudes of teachers towards scientific researches were higher than all the factors of scale as a result of their studies conducted with the teacher candidates who took the scientific research methods lesson. The attitudes of teacher candidates towards scientific researches differ significantly in terms of other factors except from the "Positive Attitude towards Research" factor according to the department at which they studied. In addition, as a result of the research, it was also stated that the gender of the teacher candidates influenced their attitudes towards scientific researches in terms of the factors as "Reluctance to Help Researchers", "Negative Attitudes towards Research" and "Positive Attitudes towards Research".

It was aimed to determine the competence level of Turkish lesson teacher candidates in the analysis of scientific researches in the study carried out by Taşdemir and Taşdemir [48]. The data in the research which was conducted with 48 students who were Turkish teacher candidates at Ahi Evran University Kırşehir Education 
Faculty, obtained based on their scientific articles, published in peer-reviewed journal. According to the findings obtained from the research, it is found that the competences of the Turkish lesson teacher candidates in determining the required characteristics of the scientific research articles were in low level compared with the competences of them regarding the dimensions related to the formality of the scientific article such as the concordance of scientific article to spelling rules, and also regarding the dimensions of problem, method, findings and results / suggestions.

Yenilmez and Ata [51] aimed to determine the attitudes of mathematics teacher candidates towards scientific research and researchers in their study. It was stated that the teacher candidates were generally neutral in terms of scientific research in the study conducted with the participation of 201 teacher candidates. It was seen that the attitude toward scientific research did not differ according to gender and academic achievement, but differed significantly in terms of grade level, the frequency of making scientific research in the future, and the graduated high school. Moreover, it was also determined that the teacher candidates want to do scientific research mostly on the subjects of limit-derivative-integral and the attitudes towards mathematics anxiety and mathematics.

It was observed that teacher candidates had positive attitudes towards educational researches in the research conducted by Konokman, Tanriseven, and Karasolak [29]. According to variables such as gender, department of education, achievement level of the measurement and evaluation lesson and scientific research techniques lesson, and scientific research experience, it was found that the attitude scores of the teacher candidates towards scientific research did not differ.

Polat [40] examined the attitudes of the students in Faculty of Education to the scientific research in the research carried out with the participation of 417 students studied at Mus Alparslan University Faculty of Education. As a result of the research, it was observed that the attitudes of the students towards scientific research were at the middle level. As a result of the same research, it was also found that attitudes of students did not change according to variables of the gender, age, the department to which registered, grade level, whether or not to take any courses for scientific research, and high school type.

Mohan and Karnan [34] investigated the relationship between Scientific Interest and Thinking Styles of High School Students. This study adopted survey method of research. Participants were 300 High School Students was randomly selected from different schools in Thiruvallur District. The level of Scientific Interest of High Students is moderate in nature. The level of thinking style of High Students is moderate in nature. It is found that there exists a positive relationship between Scientific Interest and Thinking style of High school students. There exists significant impact with respect to Medium of Instruction,
Location, Type of Management, Type of School, Parental Education and Annual Income. And there is no significant impact to Parental Occupation and Gender on Scientific Interest and Thinking Styles of High School Students.

Wang and Chang [50] were conducted to identify the structural mechanism of thinking styles and their factors in their study. The sample participated in this study was 970 college students, aging from 18 to 22, registered in various Majors of university of Science and Technology in Taiwan. After the findings were tested and concluded, their implications were also further extensively investigated and interpreted, As a result of the study, future researches were also proposed to investigate in-depth on thinking styles scale development and on the complex relationship mechanism among thinking styles, life experience, and collaborative environment.

Zhang showed that between irregular thinking style and the success has negative relation [52].

İlhan, Çelik and Aslan [25] examined the sub-dimensions of university students' attitudes towards research according to various variables. According to findings obtained as a result of the study; it was observed in terms of gender that the students differed significantly in interest, importance and motivation sub-dimensions of the attitudes towards research but did not differ in the usefulness and anxiety sub-dimensions. It was also indicated that the sub-dimensions of interest, importance, motivation, usefulness and anxiety of attitude toward research did not differ according to variables of classroom and taking of the research course. In addition, there was a significant difference in the importance, motivation and anxiety subdimensions of the attitude toward research according to the status in studying at the associate degree / undergraduate program, but no difference was found in the interest and usefulness subdimensions.

It is seen that it was aimed to determine the attitudes of university students, teachers and teacher candidates regarding scientific research according to various variables in the most of the researches in the literature. However, it was not encountered any study in which the attitudes of the teachers and the teacher candidates towards scientific research were examined in terms of thinking styles. The power of effective think that individuals have cannot be ignored in this era where science and technology are rapidly developing. From this point of view, it is considered that determining whether or not there is a relationship between the thinking styles of both teachers and teacher candidates, who are effective in educating of future individuals and their attitudes towards scientific researches, will contribute to the literature.

For this reason, analysing of the attitudes of mathematics teacher candidates towards scientific researches and their thinking styles, and whether there is a relation between these two, were determined as the purpose of this study. Answers was sought the following questions towards this purpose. 
1. What kind of distribution are the thinking styles of teacher candidates shown?

2. At what level are the attitudes of teacher candidates towards scientific research?

3. Is there a significant difference between the attitudes of teachers towards scientific research and their thinking styles?

\section{Materials and Methods}

\subsection{Research Model and Working Group}

The general survey model was used in this research which was aimed to determine the descriptive the attitudes of mathematics teacher candidates towards scientific research and their thinking styles. Since obtained the relation between attitudes of mathematics teacher candidates towards scientific research and their thinking styles, we used in this study relational model. Relational survey model is a research model which aims to determine the covariance or variation degree between two or more variables [28]. The study universe of the research is constituted of second year students studying in the Necmettin Erbakan University, Ahmet Keleşoğlu Education Faculty and Mathematics Education Department in the spring semester of 2017-2018 academic years. The main reason for the formation of the working group by 2 nd grade students is that they took the course of Scientific Research Methods that year. A total of 85 teacher candidates, 65 female and 20 male, participated in the research.

\subsection{Data Collection Tools}

Two scales were used as the 'Thinking Styles Scale' and 'Attitude Scale towards Scientific Research' in the collection of the data required for the research.

\subsubsection{Thinking Styles Scale}

The 'Thinking Styles Inventory' developed by Sternberg and Wagner [47] and the short form of 'Thinking Styles Scale' whose validity and reliability studies were done, and then adopted to Turkish by Buluş [8], were used in the research. The scale, generated by Buluş [8] with making simpler, includes 13 styles of thinking and consists of 65 items (104 items in total). It was observed in the study that the item-test correlations of the scale ranged from .31 to .84 and the alpha values for the subtests ranged from .66 (anarchic) to .93 (monarchic). The factor structure of the scale was examined by using varimax rotation with the principal component method in the mentioned study, and five basic factors having the eigenvalue of 3.1, 1.9, 1.4, 1.2 and 1.1 and explaining $68.3 \%$ of the total variance, were found. Findings of internal consistency reliability and structure validity of the scale are consistent with the results reported by Sternberg [46]. Each items of the Thinking Styles Scale was written in positive sentence format. The Thinking Styles Scale is a 7 -graded Likert-type scale. This form is structured as 'completely inappropriate (1), not very appropriate (2), somewhat appropriate (3), quite appropriate (4), appropriate (5), very appropriate (6) and completely appropriate (7).

\subsubsection{Attitude Scale towards Scientific Research}

The Attitude Scale towards Scientific Research (ASSR) developed by Korkmaz, Şahin and Yeşil [30] was used in the study. ASSR is a five-digit likert type scale consisting of 30 items taking part under four factors. Each of the items was graded as (1) completely disagree, (2) disagree, (3) undecided, (4) agree and (5) completely agree. The validity of the scale was tested by factor analysis and examining the distinctive features. Internal consistency coefficients of the inventory were calculated by using the Cronbach Alpha, Sperman-Brown formula and the Guttmann split-half reliability formula. The Cronbach alpha reliability coefficient of the scale ranged from 0.76 to 0.851 . Cronbach alpha reliability coefficient was 0.861 . Within the framework of these values; this confirms that the inventory does produce reliable measurements, in all these factors. As a result, we can say that ASSR is a valid and reliable scale that can be used in determining the attitudes of the teacher candidates in the Faculty of Education to scientific research.

\subsection{Analysis of Data}

The data obtained with the data collection tools were analyzed with the SPSS program. Frequency, standard deviation and arithmetic mean were used as statistical techniques in the analysis of the data to determine the attitudes of the teacher candidates to the scientific research and their thinking styles. In addition, a correlation analysis was used to determine the relationship between thinking styles and attitudes toward scientific research.

\section{Findings}

This section includes the findings and interpretations which were obtained as a result of analysis of data collected through data collection tools. Findings were given together with tables which include sub-problems in the direction of the research purpose.

\subsection{The First Sub-problem}

The findings belonging to the question "What kind of distribution are the thinking styles of teacher candidates shown" which is sub-problem, are given in Table 1. The mean values and standard deviations of the thinking styles are presented by calculating in Table 1 in order to determine the thinking styles of teacher candidates show 
what kind of distribution. According to the results in Table 1 , it was seen that mathematics teacher candidates participating in the research respectively, at most have the creativity-oriented legislative thinking style, which likes to determine own rule, the practice-oriented executive thinking style, the liberal (open-minded) thinking style which is open to innovation and change, and the systematically working hierarchical thinking style which determines the priority order of goals. Styles with the lowest average among the thinking styles are oligarchic and conservative (traditional) thinking styles.

Table 1. Use level of thinking Styles of Mathematics Teacher Candidates

\begin{tabular}{|c|c|c|c|}
\hline Thinking style & $\mathbf{N}$ & $\overline{\boldsymbol{X}}$ & Ss \\
\hline Legislative & 85 & 4.062 & 4.382 \\
\hline Executive & 85 & 3.927 & 4.661 \\
\hline Judgmental & 85 & 3.661 & 6.023 \\
\hline Monarchic & 85 & 3.27 & 6.028 \\
\hline Hierarchical & 85 & 3.347 & 5.547 \\
\hline Oligarchic & 85 & 2.914 & 5.963 \\
\hline Anarchic & 85 & 3.378 & 5.696 \\
\hline Global & 85 & 3.190 & 7.587 \\
\hline Local & 85 & 3.105 & 7.019 \\
\hline İnternal & 85 & 3.418 & 6.555 \\
\hline External & 85 & 3.201 & 6.536 \\
\hline Liberal (Open minded) & 85 & 3.782 & 5.857 \\
\hline Conservative & 85 & 2.571 & 7.985 \\
\hline
\end{tabular}

According to the findings in Table 1; we can say that the teacher candidates participating in the research have made most of work considering priority order, they have the features of creative thinking, productive mindset and open to change that our education system requires, they prefer activities requiring planning and do not want to be dependent on the present situation.

\subsection{The Second Sub-problem}

The findings belonging to the question "At what level are the attitudes of teacher candidates towards scientific research" which is sub-problem, are given in Table 2.

Table 2. Arithmetic Mean and Standard Deviation Results of the Attitudes of Teacher Candidates towards Scientific Research

\begin{tabular}{|c|c|c|c|}
\hline Factors & $\mathbf{N}$ & $\overline{\boldsymbol{X}}$ & Ss \\
\hline $\begin{array}{c}\text { Reluctance to help } \\
\text { researchers }\end{array}$ & 85 & 2.52 & 6.312 \\
\hline $\begin{array}{c}\text { Negative attitudes } \\
\text { towards researches }\end{array}$ & 85 & 1.95 & 5.404 \\
\hline $\begin{array}{c}\text { Positive attitudes } \\
\text { towards researches }\end{array}$ & 85 & 3.54 & 5.167 \\
\hline $\begin{array}{c}\text { Positive attitudes } \\
\text { towards researchers }\end{array}$ & 85 & 4.45 & 5.144 \\
\hline
\end{tabular}

According to the findings in Table 2; the mean positive attitude sub-factor towards the researchers of teacher candidates participating in the research was $\overline{\boldsymbol{X}}=4.45$. It can be said that attitudes of candidates towards researchers are high when it is thought that $\overline{\boldsymbol{X}}=5$ is the highest point that can be taken in the positive attitude sub-factor toward researchers. As for the sub-factor of positive attitudes towards research, while the highest score which teacher candidates was able to get was $\overline{\boldsymbol{X}}=7$, it was seen that teacher candidates had a positive attitude over average $(\overline{\boldsymbol{X}}=3.54)$. Since the findings that are the reluctance to help researchers and the negative attitudes towards research, which are included in the four factors, are negative approaches, the results should be interpreted reversely. In this context, it is possible to reach the result that the teacher candidates participating in the research are moderately willing to help research, and do not show negative attitudes towards research.

\subsection{The Third Sub-problem}

The findings belonging to the question "Is there a significant difference between the attitudes of teacher candidates towards scientific research and their thinking styles" which is sub-problem, are given in Table 3. Correlation calculation was made to determine whether there is a statistical relationship or not. 
Table 3. Correlation Values Given Relationship between the Attitude towards Scientific Research and the Thinking Styles

\begin{tabular}{|c|c|c|c|c|c|c|c|c|c|c|c|c|c|c|c|c|c|}
\hline Alt Boyutlar & 1. & 2. & 3. & 4. & 5. & 6. & 7. & 8. & 9. & 10. & 11. & 12. & 13. & 14. & 15. & 16. & 17. \\
\hline 1. Legislative & 1 & & & & & & & & & & & & & & & & \\
\hline 2. Executive &, 140 & 1 & & & & & & & & & & & & & & & \\
\hline 3. Judgmental &, $317 * *$ &, 176 & 1 & & & & & & & & & & & & & & \\
\hline 4.Monarchic & ,138 &, $228 *$ & 027 & 1 & & & & & & & & & & & & & \\
\hline 5.Hierarchical &, $344 * *$ &, $334 * *$ & ,200 &, $382 * *$ & 1 & & & & & & & & & & & & \\
\hline 6. Oligarchic &, 069 & , 196 &, $360 * *$ &, 125 &, $362 * *$ & 1 & & & & & & & & & & & \\
\hline 7. Anarchic &, $368 * *$ & , 109 &, $414 * *$ &,- 144 & ,246* &, $371 * *$ & 1 & & & & & & & & & & \\
\hline 8.Global &,- 123 &, 157 &,- 173 &, $602 * *$ &, 133 &, 057 &,$- 276^{*}$ & 1 & & & & & & & & & \\
\hline 9. Local &, 126 &, 012 & ,101 &,- 126 & ,193 &, $357 * *$ &, $585^{* *}$ &,$- 304 * *$ & 1 & & & & & & & & \\
\hline 10.İnternal &, $235^{*}$ &, 062 & ,231* & ,092 & ,266* &, $223 *$ &, $310^{* *}$ &, 156 &, $296 * *$ & 1 & & & & & & & \\
\hline 11.External &, 078 & ,265* & , 196 & , 108 &, 182 &, $241 *$ & ,091 & ,219* &, 058 &,- 171 & 1 & & & & & & \\
\hline 12. Liberal &, $546^{* *}$ &, 079 &, $512 * *$ &, 025 &, $362 * *$ & ,298** &, $497 * *$ &,- 161 &, $288 * *$ &, $407 * *$ &, 104 & 1 & & & & & \\
\hline 13.Conservative &,- 152 &, $336 * *$ &,- 049 &, 211 &, 123 &, $425 * *$ &, 021 &, $534 * *$ &, 080 &, 154 &, $349 * *$ &,- 132 & 1 & & & & \\
\hline $\begin{array}{l}\text { 14. Reluctance to } \\
\text { help researchers }\end{array}$ & ,092 &,- 009 &,- 155 & ,238* & ,063 &,- 106 & ,016 &, $294 * *$ &,- 070 & ,068 &,- 144 &,- 024 & ,026 & 1 & & & \\
\hline $\begin{array}{l}\text { 15.Negarive } \\
\text { attitudes towards } \\
\text { researches }\end{array}$ &,$- 272 *$ &,- 029 &,- 148 &, $220^{*}$ & ,067 & ,197 &,- 051 &, $287 * *$ &,- 054 & ,043 &,- 129 &,- 166 &, 168 &, $431 * *$ & 1 & & \\
\hline $\begin{array}{l}\text { 16.Positive } \\
\text { attitudes towards } \\
\text { researches }\end{array}$ & ,091 & ,059 & ,194 &,- 071 & ,096 & ,131 & ,175 &,- 101 &, $242 *$ & ,028 & , 140 &, $381 * *$ & ,036 &,- 020 &,- 110 & 1 & \\
\hline $\begin{array}{l}\text { 17.Positive } \\
\text { attitudes towards } \\
\text { researchers }\end{array}$ & ,208 & ,063 & , 180 & ,013 &,- 063 & ,031 & ,030 &,- 002 &,- 072 & ,135 & ,128 & ,218* &,- 023 & ,062 &,- 133 &, $342 * *$ & 1 \\
\hline
\end{tabular}

$* * \mathrm{p}<.01, * \mathrm{p}<.05$ 
When the relationship between the sub-dimensions of thinking styles is examined in Table 3, it is noteworthy that there are mostly positive directional relationships. It is seen that the relationship between the subdimensions of the thinking styles is between global thinking style and the monarchic thinking style at the highest $(\mathrm{r}=0.602, \mathrm{p}$ $<0.01$ ). When the findings are examined, a moderately positive relationship is observed between liberal (open-minded) and legislative $(\mathrm{r}=0.546, \mathrm{p}<0.01)$ thinking styles and liberal and judgmental thinking styles $(\mathrm{r}=0.512, \mathrm{p}<0.01)$. The relationship between traditional and global $(\mathrm{r}=0,534, \mathrm{p}<0.01)$ thinking styles and open-minded (liberal) and anarchic $(\mathrm{r}=0,497, \mathrm{p}<0.01)$ thinking styles follows those relationship levels. Moreover, there were no significant relationships between some subdimensions of thinking styles ( $p>0.05)$.

It was seen that the highest level relationship between attitudes towards scientific research are in the place between negative attitudes towards research and the reluctance to help researcher $(\mathrm{r}=0,431, \mathrm{p}<0.01)$. It was concluded that the relationship between the positive attitude towards research and the positive attitude towards researchers was at moderate level $(\mathrm{r}=0,342, \mathrm{p}<0.01)$.

According to Table 3, it was not found any significant relationship between thinking style sub-dimensions and sub-dimensions of attitude towards scientific research $(\mathrm{p}>$ $0.05)$. The highest correlation was found to be between the positive attitudes towards research and the open minded (liberal) thinking style $(\mathrm{r}=0.381, \mathrm{p}<0.01)$. Open-minded individuals are open to innovation, they like trying new ways when they do things, and they are open to researching and exploring. Individuals having behaviors with this quality are more susceptible to research and have positive attitudes toward research.

When the findings were examined, there was a low correlation between the global thinking style and the reluctance to help the researcher $(r=0.294, p<0.01)$. It is noteworthy that there is a low level negative relationship between the subdimension of legislative thinking style and the subdimension of negative attitude toward research $(\mathrm{r}=$ $-0.272, \mathrm{p}<0.05)$.

\section{Conclusions}

Thinking is a skill, and it can be taught and developed directly. Thinking styles are the forms of thinking that are unique to the individual and it is used by individual depending on the situation. Every individual realizes the act of thinking, but the thing that make individual be successful in life is the ability to think effectively. We can also say that the being aware of self-thinking style and his/her effort to replace the existing thinking style with the more effective one will increase the productivity of the individual. Bringing up querent and creative thinker individuals who have effective thinking skills and high reasoning power is among the important purposes of education. This purpose, that teacher and teacher candidates are aware of the thinking styles is a very important issue at the point of being able to think efficiently. When the importance of research and researcher is taken into consideration, attitudes of teacher candidates towards research and researchers draw attention.

It was aimed to investigate the relationship between the thinking styles of the mathematics teacher candidates and their attitudes towards scientific research in this study. It was investigated how the thinking styles of the teacher candidates who are participated in the research in the direction of the first sub-problem of the research, show distribution. It was determined that the thinking styles most preferred by prospective teachers are legislative, executive, hierarchical and liberal (open-minded) thinking styles. This may be indicate that our teacher candidates are creativity-oriented individuals, who are open to ideas, produce ideas, and perform their duties in accordance with specific plans. The least preferred thinking styles were determined as conservative and oligarchic thinking styles. It was also concluded that averages of hierarchical, legislative and executive thinking styles are high in the study conducted by Duman and Çelik [20] with the participation of elementary school teachers. It was also determined that the lowest average belongs to oligarchic and conservative thinking styles. These results have supportive nature for our study.

While in the second sub-problem of the research, it was aimed to determine the attitudes of the mathematics teacher candidates towards scientific research. The attitudes of the teacher candidates participating in the research towards scientific research are generally moderate. Yenilmez and Ata [51], found the attitudes of teacher candidates towards scientific research in moderate level in their study. Likewise, Polat [40] stated that the attitudes of the students towards scientific research were in moderate level in the study carried out with the participation of the education faculty students. These findings are consistent with the result of the study. Korkmaz, Sahin and Yeşil [31] stated that the attitudes of the teacher candidates towards scientific research are higher in accordance with all the factors. This result is not in parallel to our study. This is because; it may be that the processes and application group of both studies are different from each other.

As a result of the research, it was observed that the teacher candidates had a positive attitude in above the middle level in terms of positive attitude sub factor for researchers and positive attitude sub factor for research. This result may be indication of the desire of our teacher candidates for doing research, and their sense of wonder for exploring. It was observed that the teacher candidates had positive attitudes towards educational researches in the research conducted by Konokman, Tanriseven and 
Karasolak [29]. That the knowledge of teacher candidates for doing research and their attitudes to scientific research are in low level may be a reason of obtained results.

The relationship between the thinking styles of the teacher candidates and their attitudes towards the scientific research were examined in direction of the third sub-problem of the research the findings obtained by this study show that there is no significant relationship between the thinking styles of teacher candidates and their attitudes toward scientific research. It was found that the highest relationship was in between positive attitudes toward research and the open-minded (liberal) thinking styles. Individuals with open-minded thinking style are open to change and innovation. They like to investigate indefinite and unstructured situations [8]. They like trying new methods. For this reason, open minded individuals are more eager to investigate.

When the findings were examined, a low correlation was observed between the global thinking style and the reluctance to help the researcher. Albeit in low level, it can be say that there is a negative relationship between the legislative thinking style which is unique and likes creating its own rules, and the subdimension of negative attitude toward research. It is necessary to create more awareness in teacher candidates in terms of the importance of research, the benefit of research, the power to discover information, and the ability to question. Research culture should be established in teacher candidates. The teaching environments where teacher candidates can think more open should be provided to them.

\section{REFERENCES}

[1] Akboy, R, Argun, Y and İkiz, Y. (2003). Pdr lisans ve lisansüstü programında öğrenim gören Dokuz Eylül Üniversitesi Buca Eğitim Fakültesi Dergisi, 1, 283-292.

[2] Arkonaç, S. A. (1998). Psikoloji: zihin süreçleri bilmi (Geniş̧letilmiş 2. Bask1). İstanbul: Alfa Publ.

[3] Arseven, A. D. (2001). Alan araştırma yöntemi. Ankara: Gündüz Eğitim ve Yayıncılık.

[4] Baron, J. (2000). Thinking and Deciding, 3th. Ed. Cambridge University Press.

[5] Başol, G and Türkoğlu, E. (2009). Sınıf öğretmeni adaylarının düşünme stilleri ile kontrol odağı durumları arasındaki ilişki, Uluslararası İnsan Bilimleri Dergisi, 6(1), 733-757.

[6] Bolker, J. (1998). Writing Your Dissertation in Fifteen Minutes a Day: A Guide to Startting, Revising and Finishing Your, Doctoral Thesis. Bellingham: Owlbooks.

[7] Buluş, M. (2005). İlköğretim bölümü öğrencilerinin düşünme stilleri profili açısından incelenmesi, Ege Eğitim Dergisi, 1(6), 1-24.
[8] Buluş, M. (2006). Düşünme Stilleri Ölçeği'nin güvenirliği ve geçerliği, akademik başarı ve öğretmen adayları özellikleri, Eğitim ve Bilim, 31(139), 35-48.

[9] Buluş, M. (2016). Öğretmen adaylarında düşünme stilleri, amaç yönelimleri ve akademik başarı arasındaki yordayıcı ilişkilerin analizi, Yükseköğretim Dergisi, 6(2), 62-71.

[10] Büyüköztürk, Ş. (2016). Bilimsel Araştırma Yöntemleri. Ankara: Pegem Akademi Yayıncılık.

[11] Canbolat, N. (2011). Matematik Öğretmen Adaylarının Teknolojik Pedogojik Alan Bilgileri İle Düşünme Stilleri Arasındaki İlişkinin İncelenmesi, M.Sc. Thesis, Selcuk University Institute of Educational Sciences, Konya.

[12] Cone, J. D. and Foster, S. L. (1993). Dissertations and theses from start to finish: psychology and related fields. New York: American Psychological Association.

[13] Çatalbaş, E. (2006). Lise öğrencilerinin düşünme stillerinin akademik başarı ve ders tutumları arasındaki ilişkisi, M.Sc. Thesis, Selcuk University Institute of Social Sciences , Konya.

[14] Çelik, V. (1998). Bilgi toplumunun eğitim sistemi ve geleceğe yönelik eğilimler, Yeni Türkiye Dergisi 21.Yüzyıl Özel Sayıs1,. 4(19), 829-836.

[15] Çubukçu, Z. (2004). Öğretmen adaylarının düşünme stillerinin belirlenmesi. Trakya Üniversitesi Sosyal Bilimler Dergisi, 5(2), 87-106.

[16] Çubukçu, Z. (2004). Öğretmen Adaylarının Düşünme Stillerinin Öğrenme Biçimlerini Tercih Etmelerindeki Etkisi. XIII. National Education Sciences Congress, Malatya.

[17] Demir, Ö. ve Osmanoğlu, D. (2013). Lise öğrencilerinin düşünme stillerinin çeşitli değişkenler açısından incelenmesi, Eğitim Bilimleri Araştırmaları Dergisi, 3(1), 166-184.

[18] Dinçer, B. (2009). Öğretmen Adaylarının Düşünme Stilleri Profillerinin Çeşitli Değişkenler Açısından Değerlendirilmesi, M.Sc. Thesis, Adnan Menderes University Institute of Social Sciences, Aydın.

[19] Dinçer, B. and Saracaloğlu, A. S. (2011). Öğretmen adaylarının düşünme stillerinin karşılaştırılması, Gazi Üniversitesi Türk Eğitim Bilimleri Dergisi, 9(4), 701-744.

[20] Duman, B and Çelik, Ö. (2011). İlköğretim Öğretmenlerinin Düşünme Stilleri ile Kullandıkları Öğretim Yöntemleri Arasındaki İlişki, İlköğretim Online, 10(2), 785-797.

[21] Ellis, H. C. and Hunt, R. R. (1993). Fundementals of Cognitive Psychology. Mc Graw Hill.

[22] Emir, S. (2011). Düşünme stillerinin farklı değişkenler açısından incelenmesi, Hasan Ali Yücel Eğitim Fakültesi Dergisi, 15, 77-93.

[23] Emir, S. (2013). Öğretmenlerin düşünme stillerinin eleştirel düşünme eğilimlerini yordama gücü, Kuram ve Uygulamada Eğitim Bilimleri, 13(1), 325-347.

[24] Erdoğan, İ. (1998). Bilgi toplumu olmanın gerektirdiği eğitim paradigması. Yeni Türkiye Dergisi 21.Yüzyıl Özel Say1s1, 4(19), 870-876. 
[25] İlhan, A., Çelik, H. C. and Aslan, A. (2016). Üniversite öğrencilerinin bilimsel araştırmaya yönelik tutumlarının incelenmesi, İnönü Üniversitesi Eğitim Fakültesi Dergisi, 17(2), 141-156.

[26] Kabasakal, Ö. (1998). Bilgi toplumuna geçişte üniversitelerin önemi, Yeni Türkiye Dergisi 21.Yüzyıl Özel Say1s1, 4(19), 845-850.

[27] Karasar, N. (1999). Bilimsel Araştırma Yöntemi (9.Basım), Ankara: Nobel Publ.

[28] Karasar, N. (2008). Bilimsel Araştırma Yöntemi (18. Baskı). Ankara: Nobel Publ.

[29] Konokman, G. Y., Tanriseven, I. and Karasolak, K. (2013). Öğretmen adaylarının eğitim araştırmalarına ilişkin tutumlarının çeşitli eğişkenlere göre incelenmesi. Ahi Evran Üniversitesi Kırşehir Eğitim Fakültesi Dergisi (KEFAD), 14(1), 141-158.

[30] Korkmaz, Ö., Şahin, A. and Yeşil, R. (2011). Bilimsel araştırmaya yönelik tutum ölçeği geçerlilik ve güvenirlik çalışmas1, Elementary Education Online, 10(3), 961-973.

[31] Korkmaz, Ö., Şahin, A. and Yeşil, R. (2011). Öğretmen Adaylarının Bilimsel Araştırmalara Yönelik Tutumları. International Online Journal of Educational Sciences, 3(3), $1169-1194$

[32] Llewellyn, D. (2002). İnquiry within: implementing inquiry- based science standarts. USA: Corwinn Pres, Inc. A Sage Publications Company.

[33] Madsen, D. (1991). Successful dissertations and theses: a giide to graduate student research from proposal to completion. New York, Jossey Bass.

[34] Mohan S., Karnan P., (2017) A Study on Scientific Interest And Thinking Styles Of High School Students. International Educational Scientific Research Journal. E-Issn No : 2455-295x | Volume : 3 | Issue : 7 | July 2017

[35] Oflar, Y. (2010). İlköğretim Okulu Öğretmenlerinin Düşünme Stilleri, M.Sc. Thesis, Abant Izzet Baysal University Institute of Educational Sciences, Bolu.

[36] Oruç, Ş. and Ulusoy, K. (2008). Sosyal bilgiler öğretimi alanında yapılan tez çalışmaları, SÜ Ahmet Keleşoğlu Eğitim Fakültesi Dergisi, 26, 121-132.

[37] Özbaş, N. and Uluçınar Sağır, Ş. (2014). Sınıf öğretmenlerinin düşünme stilleri ve kullandıkları ölçme değerlendirme yöntemleri arasındaki ilişkinin incelenmesi, Ondokuz Mayıs Üniversitesi Eğitim Fakültesi Dergisi, 33(1), 365-386.

[38] Özden, Y. (1997). Öğrenme ve öğretme, Pegem Publ. Ankara.

[39] Palut, B. (2003). İlköğretim Birinci Kademe ve İkinci
Kademe Öğrencilerinin Kişisel ve Öğretmen Rolündeki Düşünme Stillerinin İncelenmesi, Ph.D. Thesis, Marmara University Institute of Educational Sciences, Istanbul.

[40] Polat, M. (2014). Eğitim fakültesi öğrencilerinin bilimsel araştırmaya yönelik tutumları, Pamukkale Üniversitesi Sosyal Bilimler Enstitüsü Dergisi, 18, 77-90.

[41] Sternberg, R. J. (1988). Mental self-government: A theory of intellectual styles and their development. Human Development, 31, 197-224.

[42] Sternberg, R. J. (1990). Thinking styles. Keys to understanding student performance. Phi Delta Kappan, 71, 366-371.

[43] Sternberg, R. J. (1994a). Allowing for thinking styles. Educational Leadership, 52(3), 36-40.

[44] Sternberg, R. J. (1994b). Thinking Styles: Theory and Assessment At The Interface Between Intelligence And Personality. In R. J.

[45] Sternberg and P.Ruzgis (Eds), Personality and Intelligence. (P.105-127) Cambridge University Press: New York.

[46] Sternberg, R. J. (1997). Thinking styles. Cambridge: Cambridge Universty Press, New York.

[47] Sternberg, R. J. and Wagner R. K. (1992). Thinking styles unventory : Unpublished test. New Haven, CT: Yale Universty.

[48] Taşdemir, M. and Taşdemir, A. (2011). Öğretmen adaylarının bilimsel araştırmaları inceleme yeterlilikleri, Selçuk Üniversitesi Sosyal Bilimler Enstitüsü Dergisi, 26, 343-353.

[49] TDK (Turkish Language Association), 2018. Contemporary Turkish Dictionary. It was accessed from www.tdk.gov.tr on 22.01.2018.

[50] Wang H.T., Chang W. (2012), A Study on the Relationship Between Thinking Styles (attitudes) and Collaboration Attitudes of College Students in Taiwan. Journal of Educational and Instructional Studies in the World May 2012, VOL: 2 Issue: 2 Article: 07 ISSN: 2146-7463

[51] Yenilmez, K. and Ata, A. (2012). Matematik Öğretmeni Adaylarının Bilimsel Araștırmaya Yönelik Tutumlarının İncelenmesi, X. National Congress of Science and Mathematics Education, Niğde, 27-30 June 2012.

[52] Zhang, L. F. (2002). Thinking styles: Their relationships with modes of thinking and academis performance. Educational Psychology, 22(3), 331-348.

[53] Zhang, L. F. (2003). Constributions of thinking styles to critical thinking dispositions. The Journal of Psychology, 137(6), 517-544.

${ }^{i}$ This research is the extended version of the presentation presented in ASOS CONGRESS, Alanya \TUREY. May, 3-5, 2018. 